\title{
Service Learning and Community Engagement: A Comparison of Three National Contexts
}

\author{
Ann Marie Thomson, Antoinette R. Smith-Tolken, Anthony V. Naidoo and Robert G. Bringle \\ 2010 \\ VOLUNTAS: International Journal of Voluntary and Nonprofit Organizations
}

22(2), 214-237

\begin{abstract}
One of the presumptions of a well-functioning, viable democracy is that citizens participate in the life of their communities and nation. The role of higher education in forming actively engaged citizens has long been the focus of scholarly research, but recently an active debate has emerged concerning the role of service as a third core function of institutions of higher learning. Service learning (SL), a teaching approach that extends student learning beyond the classroom, is increasingly seen as a vehicle to realize this third core function. By aligning educational objectives with community partners’ needs, community service is meant to enhance, among other objectives, reciprocal learning. Although the term and its associated activities originated in the United States (US), theoretical debates linking civic engagement and education extend far beyond the US context. Nevertheless, research on SL as a distinctive pedagogical approach remains a nascent field. A significant gap exists in the literature about what this pedagogical approach seeks to achieve (in nature and in outcomes) and how it is construed in non-western contexts. Using a comparative analysis across three widely different contexts, this article explores the extent to which these differences are merely differences in degree or whether the differences are substantive enough to demand qualitatively different models for strengthening the relationship between higher education and civil society.
\end{abstract}

\section{Keywords}

Service learning; Higher education; Community engagement; Civic engagement; Third sector organizations

Based on a paper presented at the International Society for Third Sector Research Eighth International Conference, Barcelona, Spain July 9-12, 2008. 


\section{Introduction}

Higher education, regardless of national or social context and geographic location, is undergoing rapid and dynamic change as societies endeavor to align the local context to national priorities and global pressures. The challenge for higher education, as intimated by Du Pre (2003), is to understand its history, articulate, and accept its role with regard to diverse constituencies in society and create an "appropriate future” within its social context.

A pedagogical strategy called service learning (SL) that links students with communities with specific educational and civic goals for both has emerged as a method for strengthening relationships between the campus and different community constituencies. SL is formally defined as: "a course-based, educational experience in which students: (a) participate in an organized service activity that meets identified community needs and (b) reflect on the service activity in such a way as to gain further understanding of course content, a broader appreciation of the discipline, and an enhanced sense of civic responsibility” (Bringle and Hatcher 1995, p. 112).

Encompassing a set of intentional educational objectives (Astin and Sax 1998; Battistoni 2002), SL is increasingly recognized as a valuable strategy for strengthening both civil society and higher education in the United States (US) and in other parts of the world including Australia (see Metropolitan Universities, 14(2), 2003), Asia (see United Board for Christian Higher Education 2002), Ireland (McIlrath and MacLabhrainn 2007) as well as Latin America, Mexico, Middle East, and Europe (see Annette 2003; Perold et al. 2003). How SL is conceived and practiced in such widely different contexts, however, is still evolving and is the principal focus of this article. Concepts such as service, SL, civic engagement, community engagement, and university-community partnerships remain contested terms across nations. We hypothesize that significant differences exist in the meaning and application of SL across these contexts.

Although research on SL is increasing (Billig and Eyler 2003; Erasmus 2005), a significant gap exists in the literature about what SL seeks to achieve (in nature and in outcomes) and how SL is construed in non-western contexts. This article explores the extent to which these differences are merely differences in degree or whether the differences are substantive enough to demand qualitatively different models for strengthening the relationship between higher education and civil society. Some of the questions we explore in this article include:

- Do recognizable patterns exist across cultures in the understanding of universitycommunity relations and SL as a viable means to build those relationships?

- What key variables need to be taken into account when considering SL in widely different contexts?

- Are certain elements (e.g. reciprocity, mutuality, reflection, political and economic empowerment of communities) common across cultures and nations? 
- How can SL contribute to the development of the third sector and participation of students in their communities after graduation?

We explore these questions by examining the concept and application of SL across three widely different contexts that vary along several dimensions: each is in a different stage of development around SL and civic engagement (mature, developing, and early); each has a distinctive political history impacting the community-university relationship (strong liberal democracy, emerging democracy, and quintessential failed state); and each varies along a continuum of relative economic and social stability (fairly stable, evolving, and highly unstable). The three cases are the US, the Republic of South Africa (RSA), and the Democratic Republic of Congo (DRC).

We organize this article into three sections. First, we explore community engagement and higher education across the three cases focusing on four overarching themes:

- Service as the third core function of both African and US universities,

- The social and political context of concepts,

- SL and community engagement in theory, and

- SL and community engagement in practice.

Second, we analyze the similarities and differences across the three cases in order to inform both the theory and practice of SL. Finally, we conclude the article by proposing a preliminary framework that will allow us to engage in subsequent comparative cross-cultural research while providing meaningful structure for practitioners interested in designing educational programs beneficial to students, faculty, community members, and the communities in which they reside.

\section{Community Engagement and Higher Education in Three Different Contexts}

One of the presumptions of a well-functioning, viable democracy is that citizens are well informed about community issues, they participate in various ways to address those community issues, and the quality of life is improved as a result of their involvement (Wandersman and Florin 1999). This is partly what drives scholarly debates about the third core function of universities in both American and African universities and its potential to influence students to involve themselves in civic matters and develop the capacity to act efficaciously. Central to these discussions is the concept of service and the introduction of SL as a vehicle to realize this potential. In this section, we examine the evolution of these debates across the three countries by the four themes delineated above. Table 1 provides a summary of our comparative analysis across seven dimensions. ${ }^{1}$

\section{Service: The Third Core Function of Universities}

Internationally, universities increasingly include service as a third core university function together with teaching and research. Of the three, the service function may be the most contentious because it involves an epistemological debate about the role of knowledge in society. 
Central to this is the mode 1/mode 2 knowledge creation debate (Gibbons 2006) that juxtaposes knowledge for knowledge's sake (mode 1) with useable knowledge for the benefit of society (mode 2). In contemporary society, increasingly louder voices demand that universities generate socially useful knowledge that integrates with other forms of knowledge in the knowledge economy. This differentiation signifies a shift from the 'truth' as main criterion to 'what use is it' (Gibbons 2006; Le Grange 2005).

In the US, higher education has always played a role in developing good citizens, and historically many different types of community-university relationships have emerged (Peters et al. 2006; Thelin 2004) ranging from cooperative extension, outreach and continuing education programs to top-down administrative initiatives, faculty professional service and research, student volunteer initiatives, and, more recently, SL courses (Thomas 1998). Similarly, different pedagogical techniques have emerged around these community-university interactions. Levine (2003) notes, for example, that numerous pedagogical approaches for civic learning abound such as classroom instruction on civics, moderated discussions of current events, student governance and community activities, simulations, and role plays. The emergence of the field of SL is a relatively new innovation in this discourse that has heightened attention to the nuances of the civic domain, social responsibility, and the rules of engagement between institutions of higher education and society (Astin and Sax 1998).

Service learning (a pedagogy that deliberately integrates the service function of the university into its teaching function) has stimulated a renewed commitment to civic engagement (Langseth and Plater 2004), and a departure from traditional university approaches to outreach that are hierarchical and elitist (Kellogg Commission 1999). Furthermore, it departs from the traditional tripartite division of teaching, research, and service. Civic engagement is not merely a substitute for professional service or application but is a particular way of doing teaching, research, and service in and with the community (Fig. 1).

Although there is a strong zeitgeist in American higher education to explore the public purposes of higher education and improve on traditional models of engagement, the distinctly historical preference for limited representative government and private interests may help to explain the more decentralized and individualized nature of SL as practiced in institutions of higher learning in America. Except in the case of land-grant universities, the US government does not mandate that American universities engage in community or national development; that is largely left up to mission statements, university trustees, administrators, and faculty (Table 1: Dimension 3). Some US accrediting bodies (e.g. Higher Education Commission) have added community engagement components to their criteria, but the engagement agenda is largely discretionary and open to self-definition by institutions within the context of their individual mission statements (Table 1: Dimension 4).

In the RSA, on the other hand, the term community service was historically viewed and practiced as voluntary initiatives of students at the periphery, while the university continued its core focus 
on teaching and research (for example, USKOR at Stellenbosch University and SHAWCO at the University of Cape Town). The linkage between service and academic work only surfaced when the ANC government instituted a higher education transformation plan with the primary goal to change the racially divided institutions of higher education to non-racial merged entities. This plan was part of a comprehensive nation-(re)building effort as espoused in the Reconstruction and Development Programme (ANC 1994) meant to redress the inequalities of the apartheid legacy. In seeking to transform the inherited educational landscape, a White Paper on the Transformation of Higher Education (Department of Education 1997) identified community engagement as an integral and core part of higher education in RSA. The White Paper challenged higher education institutions to demonstrate social responsibility and their commitment to the common good by making available expertise and infrastructure for community service programs (Table 1: Dimension 3).

Multiple analyses of the implementation of SL in RSA (Bender 2007; Erasmus 2005; Lazarus 2001; Perold 1998) capture the transformation of South African higher education brought about by the 1997 White Paper and the intervention of the NGO, Community-Higher EducationService Partnerships (CHESP). Externally funded by the Ford Foundation, CHESP was instituted to promote community engagement and SL in higher education in RSA during the last decade. Research sponsored by CHESP on the role of community service in higher education reflects the status of community service in RSA at the time (Perold 1998). Recommendations in the Perold report renewed the call to all stakeholders to support institution-driven curricular-based community service instead of the prevailing individual-level volunteerism occurring at the periphery of institutions. The inclusion of community engagement and SL in the follow-up legislation was to a great extent the result of CHESP's advocacy and collaboration with government. Recent accounts of the state of community engagement and SL in RSA indicate that it is fairly widely practiced among the 23 public universities in the country (Lazarus 2007).

Despite the fact that community engagement is widely practiced, the Department of Education (DoE) did not provide any material means to achieve the goals of these initiatives (Department of Education 2004). A notable distinction of SL in RSA, then, is the pivotal role of the university in the broader transformation agenda of the state. Although that role was not supported with government funding, the policy mandate from the government is clear: universities should become more responsive to the socio-economic issues of the country (Castle and Osman 2003; Fourie 2003).

In the DRC, neither the "civic engagement” approach of US universities nor the top-down approach of the South African government applies (Table 1: Dimensions 3 and 4). Belgium’s colonial legacy in the DRC has had a devastating effect on higher education in the DRC. Designed to provide only the most basic education for a workforce capable of supporting the colonial regime, Belgian education policy was, writes Browne (2001), “an education for servitude, rather than an education that made [Congolese] independent thinkers [or] problem- 
solvers” (p. 340). It is not surprising then, that in 1960, at the time of independence only 16 Congolese had earned a university degree (Browne 2001).

The 30-year legacy of military dictatorship and kleptocracy of Mobutu Sese Seko that followed in the wake of Belgium's colonization did little to transform the education system despite nationalization of all schools in 1971. Higher education remained suspect. Indeed, Mobutu never hesitated to shut down public universities whenever students and faculty became politically active. Overall, universities, in contrast to professional schools, remained separate from society. The core function of the Congolese university post independence was to train educated elite capable of conducting fundamental research in various disciplines (World Bank 2005). To this day, university instruction follows the "cours magistraux" where professors lecture and students take examinations (Browne 2001). Community service is seldom mentioned as a core function of the Congolese university. This does not bode well for higher education and its potential for creating civically minded students who will actively engage in democratic politics or community development.

\section{The Social and Political Context of Key Concepts}

That words matter is hardly a contested idea, yet scholars, practitioners, and policymakers alike continue to act as though they hold similar meanings in widely different settings (Table 1: Dimension 7). The term "civic engagement" is used in America to connote a means by which teaching, research, and service can be integrated to create civically minded graduates. As such, its meaning is linked to the overall consensual (albeit theoretical) understanding of the relationship between government and its citizenry. Civic engagement in an African context, however, where the relationship between citizens and governments remains largely undefined, may or may not be conceived in the same way.

In both the American and African contexts, the term "civic" is political but in different ways. In RSA and the DRC, the term "civic" has a political connotation that does not resonate with individual capacity building and democratic empowerment processes aimed at improving quality of life. In the US, on the other hand, the focus on individual empowerment is directly rooted in the expected rights and responsibilities of citizens who hold their governments accountable through the democratic principle "government by the people." In RSA and the DRC, the term civic remains highly contested given the yet developing (in the case of RSA) and non-existent (in the case of DRC) democratic state.

For this reason, it is not surprising that in RSA, the term civic engagement is not used in the higher education context. Instead, the term of choice is "community engagement" when referring to the university's third core function, a term that acts as an umbrella term to cover a wide variety of types of engagement (including SL) across each of RSA's 23 institutions of higher learning (Bender 2007; Lazarus et al. 2008). In some South African languages, however, there is no term with the same meaning as engagement. Stellenbosch University has adopted the term 
“interaction" as it presupposes a two-way communication or influence and equality between the interacting parties. Today, the terminology continues to evolve moving away from "community engagement” to “a scholarship of engagement” (Higher Education Quality Committee/JET Education Services 2006). “Community engagement” in RSA, then, has many names and manifestations and little or no research has been done on the scholarship of engagement in RSA (Bender 2007; Bringle and Erasmus 2005).

In the DRC, a paucity of research on the subject makes it difficult to determine the extent to which students engage in community service at their universities today. No direct translation exists for the terms “community service," “community engagement," or "civic engagement” in the context of university-society relations (although the term "civisme" is used to broadly connote civic-mindedness). By far, the most common terms used refer to internships such as "l’internat" (referring to vocational training) or "le stage" (referring to work placement) implying a narrow conceptualization of community involvement as a pre-professional educational activity without obvious intentions toward developing civic responsibility (Thomson 2006).

Congolese university students, however, do have a legacy of student activism that began in 1964 (and occurred again in 1971 and 1990), when students at the former Lovanium University Center "asked for more participation in the organization and operation of the university in the form of a co-management model [demanding] the Africanization of the conception, orientation, and methodology of both teaching and research" (Lelo 2003, p. 269). This kind of “civic engagement” evident in the 1964, 1971, and 1990 student movements, however, was narrowly confined to education reform and the immediate living and working conditions on university campuses, not a more widespread call for political reform and social justice at the national level. Nevertheless, that they did confront an existing status quo suggests Congolese students have a legacy of activism that could be channeled toward community development, civic engagement, and SL if the political and social conditions were stable (Table 1: Dimension 6).

In the US, a distinction is made between the broader term, community involvement (defined solely by location of the activity; i.e. teaching, research, and/or service in the community), and civic engagement, which is more narrowly defined as teaching, research, and service that is both in and with the community (Bringle et al. 2006). Community involvement has no geographic boundaries and includes university work in all sectors of society (e.g. nonprofits, government, and business). In contrast, civic engagement is "civic" in the sense that it expects relationships and methods of participation among parties to be fair, participatory, and democratic, and to honor different ways of knowing and different knowledge bases (Table 1: Dimension 7).

Two other terms in this discourse that do not easily travel across contexts are "service" and subsequently "SL.” In the US context, the term "service” remains an enduring part of the American psyche rooted in the civic virtue necessary for democratic citizenship and civic participation expressed through moral individualism (Perry and Thomson 2004). Hence, in 
general, Americans do not balk at the term though for some, the term connotes charity in contrast to social justice (Morton 1995).

In RSA, on the other hand, “service” is a contested term and cannot be isolated from RSA's racialized history characterized as it is by master-servant relationships and the paternalistic charitable activities that were typical manifestations of this grossly unequal relationship dynamic. "Service" in this context is a loaded term that brings with it a deeply ingrained recollection of subordination, oppression, and injustice. For this reason, several South African universities have chosen to use the more inclusive concepts of community interaction or community engagement. Given the transformational and developmental intentions that are invested in the university-community relationship in post-apartheid RSA, the term "engagement" may better reflect the values of democracy, mutuality, and reciprocity intended by this third core university function. The term 'curricular community engagement', denoting community engagement in a curricular context, has also recently surfaced in literature (Bender 2008).

Like the RSA context, "service” in the DRC, is also a hotly contested term evoking memories of Belgian colonial rule. When talking with Congolese in general the negative connotation of service within the colonial context emerges naturally. "Service" is often equated with paternalistic and hierarchical relationships between Congolese and their white colonizers. Lessons learned from the RSA experience suggest that efforts by faculty to introduce SL in DRC universities should seriously consider using a less politically charged word. Community interaction or community-based learning rather than "SL" may prove to be a more viable term.

\section{SL and Community Engagement in Theory}

In both the US and RSA, SL as defined by Bringle and Hatcher (1995) helps to differentiate SL from other types of educational experiences that take place in the community (e.g. internship, practicum, field-based instruction, and cooperative education) and SL from volunteering (Furco 1996). In the US and RSA, unlike many practica and internships (which focus on preprofessional skill development), SL is linked to a course and has the intentional goal of developing civic skills and dispositions in students. Unlike volunteering, SL represents academic work in which the community service activities are used as a "text" that is interpreted, analyzed, and related to the content of a course in a way that permits a formal evaluation of academic learning. Thus, in SL, academic credit is not given for engaging in community service; rather, academic credit is based on the academic learning that occurs as a result of the community service.

Furthermore, the service activities are intentionally selected to align with the educational objectives of the course and with community partners' agendas to ensure that the community service is meaningful not only to students but also to third sector organizations, their clients, and community residents. Thus, high quality SL classes demonstrate mutual benefits and reciprocity 
between the campus and the community with each giving and receiving, and each teaching and learning.

In RSA, the situation is complicated by the fact that while the theoretical foundations of SL have been extensively influenced by the development of the field in the US, the impetus for the introduction of this new form of pedagogy has been mandated by the ANC government as a mechanism by which South African universities could become a knowledge-based instrument of social equity. This places South African faculty and community engagement administrators in the difficult position of responding to a top-down driven mandate with a model that is US in origin. In response to the South African government's mandate, international consultants were contracted to facilitate South African faculty and community engagement administrators to implement SL in South African universities (Lazarus 2007). Definitions of SL and community engagement used in RSA have been adopted from US colleagues and applied to the South African context. Very few, if any, new definitions of SL have been developed within the RSA context over the last decade (Bender 2007).

South African scholarship in the field is increasingly assertive about the need to reconsider the adaptation of the US-based model to the South African context. As Bender (2007) eloquently articulates:

Collaboration with USA scholars and champions has enhanced the South African academic staff members' scholarship of engagement, critical reflective thinking and the urge to develop grounded theory and a conceptual framework for the South African context of higher education. Yet if these models are uncritically assimilated into the South African context, [scholars] are ignoring the highly influential aspects of language, culture and content (p. 130).

The extent to which South African scholars and administrators will successfully adapt US-based models of SL to a South African cultural context or whether the model will remain largely American in practice remains an open question. As SL has a long history and gestation in the US, in RSA it is hardly a decade old.

In the DRC, anecdotal evidence suggests that SL as discussed in this article is non-existent in Congolese higher education. What is true for most African universities in general is also true for Congolese universities: "[with] few exceptions (such as running teaching hospitals and allowing public access to university library facilities)," writes Lulat (2003), “most universities [in Africa] have essentially been ivory towers” (p. 28). This may partly explain why student activism in the DRC has historically been limited to the narrow confines of university life rather than larger political, economic, and social issues.

Today, no comprehensive education policy exists in DRC. In its 2005 review of education in the DRC, the World Bank cites a litany of reasons why this is so: persistent political and economic 
instability, a precipitous fall in public expenditures on education (expenditure per student is only one-quarter the average public expenditure per student for sub-Saharan Africa), weak administrative infrastructure, nearly complete reliance on private student fees to fund university education, a severe shortage of university professors, and an outdated curriculum that has not been revised since 1981 (World Bank 2005). Under these conditions, fostering a pedagogy of community engagement is hardly a priority. With professors frequently teaching in several universities at once, traveling from one institution to the next in the same day, no infrastructure currently exists capable of sustaining community engagement as a core function of the university.

Currently, in contrast to RSA, the DRC government's role in higher education is limited given the continued instability of the country. As long as institutions of higher learning remain relatively quiet and do not challenge the status quo, universities will be left largely ignored by the DRC government. Given the continued political and economic instability in the DRC (Afoaku 2005; Njongola-Ntalaja 2004; Trefon 2004), one might reasonably speculate that were the implementation of SL programs at universities to follow the transformational agenda of the ANC government in RSA, it is highly likely that the university, its faculty, and students could experience serious and negative consequences. Like RSA, the SL context in the DRC has serious political consequences not found in the United States. The growing body of literature on SL in the US and in RSA will have significant impact on the theoretical foundations for SL in the DRC (and elsewhere in Africa).

\section{SL and Community Engagement in Practice}

There are two dominant themes that SL makes salient for new models of civic engagement in the US: (a) education of students in civic skills for democratic processes and (b) community outcomes in addition to academic outcomes. Within the US context, Westheimer and Kahne (2003) identified three distinct domains of civic education: (a) the personally responsible citizen, (b) the participatory citizen, and (c) the justice-oriented citizen. Battistoni (2002) conducted an analysis of the different dimensions of citizenship with reference to the content domains and paradigms of the disciplines and professions. His analysis identifies seven distinct approaches to civic education: (a) civic professionalism, (b) social responsibility, (c) social justice, (d) connected knowing and the ethic of caring, (e) public leadership, (f) public intellectual, and (g) engaged or public scholarship.

Service learning can facilitate achieving learning objectives in each of these domains, although how and with what success remains to be explored through further research. To the degree that skills and knowledge for democratic processes are important to educators, SL (properly designed and implemented) provides a means for students to practice and develop skills, relate their activities to appropriate academic content, and develop motives to sustain their community involvement (Astin and Sax 1998). 
Current research on students in American universities demonstrates that prior to entering college the vast majority of students have volunteered in local communities but the dominant motives for civic engagement are (a) altruistic and humanitarian concern for others and (b) understanding the degree to which volunteering provides opportunities for new learning experiences and for using knowledge, skills, and abilities (Bringle et al. 2006). American college students are not particularly motivated to engage in traditional politics and volunteering serves as a source of civic engagement that is largely apolitical. Thus, in most ways, American college students view their voluntary civic engagement as politically benign. Generally, results across research studies support the conclusion that American college students have the highest interest in charity activities and the lowest interest in social change activities (Moely and Miron 2005; Morton 1995).

The second dominant theme that SL makes salient for new models of civic engagement in America is: community outcomes in addition to academic outcomes. Service learning educators must avoid the risk of focusing predominantly on student outcomes, to the exclusion of community outcomes. However, well-designed SL courses that engage students in activities that have significant community outcomes promote a cluster of cognitions, motivations, and attitudes that may increase the likelihood of positive community outcomes in the future (Astin and Sax 1998). In turn, these activities can develop an interest in and advocacy for the third sector across a student's life and career.

Service learning places students in community environments in which they interact with persons who are different from themselves in terms of racial, economic, religious, or other background characteristics. Research studies in America have documented that SL has an impact on student perceptions, values, and behaviors related to diversity. For example, SL has been found to: increase student sensitivity to diversity (Driscoll et al. 1996); increase student knowledge of, and ability to get along with, people of different races and cultures (Astin and Sax 1998); increase student tolerance and decrease stereotyping (Eyler and Giles 1999); and increase students' ability to work with diverse groups (Osborne et al. 1998). Finally, Astin et al. (1999) conducted a longitudinal survey study and found that the frequency of volunteering during the last year of college was positively correlated with reported promotion of racial understanding 9 years after graduation.

Viewed from the perspective of outcomes (student and community), SL becomes the impetus for American higher education to examine both the methods and goals of a broad range of activities in higher education (Bringle et al. 1999; Colby et al. 2003; Langseth and Plater 2004). Given the relative stability of the political, economic, and social environment in which American higher education has evolved, these activities (including SL) have also had the benefit of time, experimentation, and research to inform their development. In RSA and the DRC, however, the environment in which higher education and SL have evolved has been far from stable and marked with a paucity of resources and opportunities for experimentation and research. 
One of the defining attributes of SL in the US context is that, along with academic learning, it also aspires to students' civic growth (Ash et al. 2005). Thus, in addition to "serving to learn," SL intentionally focuses on "learning to serve.” In RSA, additional objectives include: students' exposure to the structural conditions in communities; engagement with causative contextual considerations for the manifestation of prevailing social conditions; cross-cultural interaction (this is a significant consideration given that RSA's neighborhoods remain largely racially segregated); and the opportunity to engage in community development initiatives and social change. These educational goals can best be accomplished when students are involved in educationally meaningful service through third sector organizations and in direct collaboration with residents of communities in which the engagement activities take place.

The extent to which universities have integrated community engagement into their core functions will unequivocally affect the third sector organizations with which they engage, for it is this sector that has formed an integral part of the development of community engagement and SL in both the US and in RSA. In contrast to the US, however, no consensus exists in RSA regarding expectations of citizens about their very young democracy. In general, the term civil society refers to: "those non-for-profit organizations and groups or formations of people operating between the family and the government, which are independent, voluntary and established to protect or enhance the interests and values of their members” (Camay and Gordon 2002, p. 2). In RSA, third sector encompasses a wide range of organizational types including those that focus on meeting basic needs (even as communities, families, and individuals fight for survival in the face of poverty and discrimination) as well as those characterized by progressive values and norms (e.g. political, economic, and gender equality).

This diversity poses significant challenges for creating university-community partnerships in RSA. Marais and Botes (2006), for example, contend that the nature of community service partnerships with third sector organizations could easily lead to an overemphasis on the role of the university at the expense of community. Marais et al. (2007) also draw attention to ways in which the power differential in SL partnerships may be mitigated against relationships of equality and mutuality with community partners. SL initiatives with community partners must be informed by a shared vision, encompass clarification of roles and expectations, and allow for collaborative decision making, reciprocity, and attaining mutual goals and benefits.

Despite the power differential in SL projects, Marais et al. (2007) argue that both university and community needs and agendas have to be accommodated in negotiated partnerships. Naidoo and Van Wyk (2003) describe a community SL project in South Africa that sought to intentionally operationalize community psychology values (e.g., ecological perspective, empowerment, prevention, sense of community, and social justice) while actively pursuing locally articulated community development objectives in a small peri-urban community. Creating participative processes where the voices and involvement of local residents are included is crucial to the 
success and sustainability of community-based endeavors in RSA and elsewhere (Prilleltensky 2001).

Creating partnerships with local community residents and third sector organizations for the benefit of the community fits well with the South African government's mandate to incorporate higher education into the national agenda for community development and social transformation of society. Different from the US model (which typically refers to campus-community partnerships), SL practitioners in RSA adopted the CHESP triad model of partnerships among the university, third sector organizations, and residents of the community (HEQC/JET 2006). At Stellenbosch University, for example, the rationale to adopt this model was to avoid duplicating existing services in communities which would further fragment the existing third sector and its organizations.

Students involved in SL at Stellenbosch are required to do a situation analysis of the organization where they will work as well as in the communities where the organization resides, enabling them to work within the parameters of the organization's mission while taking into account the macro development processes that influence the micro situation. In RSA, most universities have an historical background linking it to race, language, culture, and political preferences. Higher education discourse refers to universities as "previously disadvantaged” or "historically white." These ascriptions pose one of the most difficult challenges for universities seeking to interact with communities outside the university. For example, faculty reflection during several capacity building seminars in 2005/2006 suggested that communities of one race tended to show resistance to interaction with students from another race while predominantly white students were hesitant to work in predominantly black community localities. Even between non-white racial variations, issues of classism surfaced in face-to-face interactions. Black middle class students would be met with distrust, while the students themselves would act within their own perceptions of such communities (SU 2007).

Third sector organizations can play a pivotal role in neutralizing power differentials that might exist between community members and the university because both stakeholders normally enjoy the trust of these organizations (HEQC/JET 2006). On the positive side, research on perceptions of community organizations show that students provide meaningful resources to organizations in reaching their goals (Mitchell and Humphries 2007; Nduna 2007). The functions they perform are administrative, skills training, fundraising and improving existing systems.

In the DRC, lessons learned from a nascent attempt to design a SL program at one of DRC's premier private universities suggest that in a country with no reliable basic public services (including roads, potable water, electricity, and health services) and a decimated education system, Maslow's hierarchy of needs may determine the extent to which SL is a luxury of higher education or a necessity. Furthermore, the logistics of a SL program-where relationships need to be built between students, the university, and third sector organizations but the infrastructure 
does not exist to support those relationships-have proven to be a nearly insurmountable challenge.

Despite the fact that the DRC represents a quintessential failed state (Rotberg 2003), there are pockets of civil society that thrive in the midst of chaos created by the overall lack of governmental infrastructure. According to Trefon (2004), since Congolese have experienced intense social stress for decades, one would expect that social institutions would have collapsed. Instead, he argues, at least in Kinshasa (DRC's capital city of roughly eight million), social institutions "appear to be diversifying and even strengthening...through the development of civil society institutions" [the effect of which has been] the "reinvention of order" from the bottom up (Trefon 2004, pp. 2, 5).

These new forms of social order were created out of necessity; in the absence of any public services, widespread hunger, and insecurity, millions of Congolese have formed associations, local grassroots helping networks, or participated in what Giovannoni et al. (2004) call the "NGO phenomenon” (p. 100). In Kinshasa alone, some estimates suggest as many as 1300 NGOs have been created since 1990 and many Kinshasa residents (especially intellectuals) are beginning to place greater faith in third sector organizations than government to provide what the state has been unable to provide: peace, improved quality of life, democracy, and poverty alleviation (Giovannoni et al. 2004, p. 101).

That the third sector seems to be thriving in Congo (at least in Kinshasa) suggests multiple opportunities for Congolese university students to engage in local communities through SL. The empirical question not yet addressed, however, is the extent to which nascent third sector organizations in Kinshasa (stimulated by the need to survive and the presence of external funding sources) have the overall capacity to host students implementing SL projects. As university students could be the very ones most capable of strengthening the capacity of third sector organizations in DRC, program design is paramount. But how one builds a program of engagement among "partners” of unequal influence is neither straightforward nor assured, especially when one organization, the university, holds so remote and prestigious a position in Congolese society. As the South African experience with community interaction has demonstrated, without the deliberate creation of infrastructure, skilled university staff, and processes where the voices and involvement of local residents are included, the success and sustainability of community-based endeavors is unlikely to occur (Prilleltensky 2001).

\section{Discussion of Similarities and Differences Across the Three Cases: Implications for Theory and Practice of SL}

The comparative analysis across three very different countries with wide variation on historical, political, economic, and social factors suggests that overall, the application of an American version of SL may not easily occur in RSA or DRC. SL may not be easily applied in the same way in all contexts. Some adaptations are matters of degree, however (e.g., developing a new 
sort of practicum based on SL principles rather than professional development), others are substantive (e.g. pursuing ameliorative activities rather than advocacy activities so as not to place in danger young university students doing community service in highly unpredictable environments). Furthermore, forming long-term partnerships with third sector organizations may prove more important in both the DRC and RSA than in the US where SL programs tend to focus on short-term community service projects and activities.

The political and historical environment in which SL is practiced matters. The relationship between higher education and society is seriously challenged when a country has no functioning government (as in the DRC) and when citizens have no consensual understanding of what constitutes "civic" in the context of "democratic civic engagement" (as in both RSA and the DRC). That widespread democracy has never really been practiced in the DRC is reason to question the relevance of SL as a means to teach democratic skills in a country whose citizens are primarily concerned with day-to-day survival. Ironically, in a well-established democracy like that in the US, college students tend to view civic engagement largely in terms of charitable actions through third sector organizations rather than political mobilization. Thus, in most ways, American college students view their civic engagement as not politically contentious and rarely dangerous.

Although American universities have occasionally been hotbeds of political activism (as in the 1960s), this activism is generally tolerated by society. In contrast, university students in RSA and DRC face a less predictable environment. Involving students in civic matters can be dangerous, such as fulfilling a political agenda (e.g., transformation in RSA) and “taking sides" in a politically contentious situation (e.g., in the DRC). Furthermore, economic conditions in both RSA and the DRC are dire and it is not at all clear that extreme conditions such as these can yield the kind of "civic" engagement expected of citizens in western democracies. This is further complicated, of course, by the fundamental differences in understanding of principal concepts like service, civic engagement, and community service.

In many cases, for example, community service is equated with charity work, reinforcing the perception that poor communities are helpless (Bringle and Hatcher 2006; Lazarus 2005). Practitioners of SL in all three countries raise concerns about the use of service to describe community-based learning pedagogies focused on developing civic skills in students. As consistent as these concerns are, however, the basis of concern differs in countries with a colonial heritage of brutality and master-servant relations. Still, the relevant and immediate concern centers on the risk of students viewing their community activities as something that is done to and for others but not with others. Engaging students so that they respect local ways of knowing, practice democratic and egalitarian approaches to interactions, develop intercultural competencies, and approach SL activities in ways that develop efficacy for all participants are challenges that educators must address in designing effective courses for their students regardless of culture and context. 
What the institutions of higher learning in RSA and the US have in common is a commitment to the tri-partite functions of teaching, research, and service. At least in RSA and the US, a commitment exists to developing socially responsible young people. In the DRC, the service component is, in practice, either secondary to the principal core functions of teaching and research or non-existent (because it is not feasible). What RSA and DRC universities have in common is a host of additional developmental challenges (not found in the US) such as dire fiscal limitations and inability to meaningfully address developmental issues perpetuated by weak government structures. Furthermore, like the rest of Africa, RSA and DRC universities face the challenge of reconsidering their roots within the African culture.

These concerns make it all the more important to consider a framework that might inform the design and implementation of SL programs in different contexts. How these programs are designed has serious implications for the third sector in each country particularly because third sector organizations are significantly affected by SL programs. SL programs are also equally affected by the extent to which third sector organizations have the capacity to meaningfully absorb incoming students and how they can be strengthened through SL.

\section{Toward a Preliminary Framework: Research and Design of SL Programs}

In a recent text on Community Psychology in RSA, Naidoo et al. (2007) present a continuum depicting a range of psychological interventions from mainstream approaches (e.g., direct social service) to more collective approaches based on transformative actions (such as advocacy, lobbying and social activism). In a similar vein, SL programs can be characterized as being more individualistically or collectively oriented and as having more ameliorative (charitable) or transformative motives or goals. This is illustrated in Fig. 2. In general, charitable or ameliorative activities (e.g., providing relief to people affected by flooding in an informal settlement) will involve community service, in contrast to more collectively oriented activities (e.g. addressing needs through participative processes with local residents and organizations) that are more akin with community development.

Where a SL program might fall on this continuum depends on a number of factors that demand careful consideration. These include but are not limited to: (1) both the national and community specific micro and macro contexts, (2) the goals and expected outcomes of a community SL approach or philosophy (different community service paradigms exist among stakeholders), (3) the extent to which stakeholders involved are able to negotiate agreed upon understandings and approaches, and (4) the capacity of the third sector to support SL programs.

Faculty, students, community engagement administrators, and representatives from third sector organizations and communities can use this conceptual framework to negotiate the goals and outcomes - and hence the design — of SL programs as they carefully consider both the external

and internal factors that vary across political, economic, and social factors. Design should always begin by: (1) identifying key stakeholders (e.g., students, community members, third sector 
organizations, etc.), (2) jointly analyzing both the macro and micro contexts in which SL is to take place, and (3) jointly determining the specific objectives of the SL program.

Drawing from the analysis in step 2 above, stakeholders should then identify the developmental goals and expected outcomes of SL through their own particular lenses and together negotiate the particular design most appropriate based on steps 1 and 2 above. This approach is timeconsuming and therefore difficult to achieve. The up-front costs in time, energy, and negotiation may prove too costly for many university faculty, community engagement directors, third sector organization staff, and/or community members yet the long-term benefits may prove worthwhile across a longer time perspective of engagement.

From a university perspective, community engagement by institutions of higher education is staked on the intersection of academic interests (e.g. student learning; faculty scholarship) and community-defined outcomes. This territory needs to be negotiated in the design of community engagement activities so that an appropriate balance between mutual and competing interests can be achieved. Within all three contexts studied here, this often includes discussions with third sector organization staff who have a stake in mutually beneficial outcomes not only for their own organizations and local communities but also for students and faculty. However, third-sector staff have a vested interest in their organizations and their careers, which might create a limitation on their capacity to represent the constituencies they serve. For this reason, it is appropriate to also represent those groups in conversations about common interests and best designs for joint work. Respecting the special interests of multiple constituencies is a challenging, yet richly rewarding endeavor, when designing community engagement activities through SL programs.

\section{Conclusion}

We approached this article with a hypothesis that significant differences exist in the meaning and context of SL and civic engagement across nations and cultures. The extent to which those differences are matters of substance or degree continues to drive our research agenda. An examination of higher education in the US and two African countries frames our analysis by demonstrating significant differences in historical, political, economic, and social conditions that shape the relationship between institutions of higher learning and the societies in which they reside.

This in-depth examination of university-community interactions and SL in the US, RSA, and the DRC suggests certain variables do emerge that influence how SL manifests itself in all three cases. These include: (1) external structural conditions (e.g., history, political, and economic conditions) and internal issues (such as power differentials, differences in interpretation of terms), (2) motivations for engaging in community service (e.g., amelioration of immediate needs (charity) or social transformation and collective social justice), and (3) the extent to which a third sector exists with the capacity to support SL programs. 
Despite the fact that patterns do emerge demonstrating significant differences in the social, political, and historical contexts that influence how stakeholders approach and interpret SL and CE by higher education, it remains unclear the extent to which the intent of SL (as a particular means of preparing students to be socially responsible and engaged in strengthening the third sector) varies across contexts. It also remains unclear how the variation in contexts influences the actual implementation and practice of SL. Both of these remain empirical questions that need to be part of a larger comparative research agenda. In all three countries, however, apart from the government mandate to redress inequalities and help fight poverty in RSA, the primary role of higher education remains to produce quality graduates for a skilled workforce.

Schudson (2003) notes that different political systems need different types of citizenship skills. Thus, the answers to these questions about civic objectives are context specific and will likely be different (Annette 2003). Our analysis illustrates that because the outcomes might differ across countries, the design of pedagogies to develop these skills will also need to be tailored to the particular political and social context. Nevertheless, there are some values (e.g., reciprocity, mutual benefit, democratic processes, and community voice) that are fundamental to community engagement in general and SL in particular that may transcend geographical, historical, political, and economic boundaries (Bringle et al. 2007). 


\section{References}

Afoaku, O. G. (2005). Explaining the failure of democracy in the Democratic Republic of Congo: Autocracy and dissent in an ambivalent world. Lewiston, NY: Mellen Press.

ANC. (1994). The reconstruction and development programme. A policy framework. African National Congress. http://www.anc.org.za/ancindex.html.

Annette, J. (2003). Service-learning internationally: Developing a global civil society. In S. Billig \& J. Eyler (Eds.), Deconstructing service-learning: Research exploring context, participation, and impacts (pp. 241-249). Greenwich, CT: Information Age.

Ash, A. L., Clayton, P. H., \& Atkinson, M. P. (2005). Integrating reflection and assessment to capture and improve student learning. Michigan Journal of Community Service Learning, 11(2), 49-60.

Astin, A. W., \& Sax, L. J. (1998). How undergraduates are affected by service participation. Journal of College Student Development, 39, 251-263.

Astin, A. W., Sax, L. J., \& Avalos, J. (1999). The long-term effects of volunteerism during the undergraduate years. Review of Higher Education, 22(2), 187-202.

Battistoni, R. M. (2002). Civic engagement across the curriculum: A resource book for service learning faculty in all disciplines. Providence, RI: Campus Compact.

Bender, C. J. G. (2007). Pathways of change for integrating community service-learning into the core curriculum. Education for Change, 11(3), Special Issue: CSL.

Bender, C. J. G. (2008). Curriculum enquiry about community engagement at a research university. South African Journal for Higher Education, 22(6), 1154-1171.

Billig, S. H., \& Eyler, J. (2003). The state of service-learning and service-learning research. In S. H. Billig \& J. Eyler (Eds.), Deconstructing service-learning: Research exploring context, participation, and impacts (pp. 253-264). Greenwich, CT: Information Age.

Bringle, R. G., \& Erasmus, M. (Guest Editors). (2005). Research and (community) service learning in South African higher education institutions. Acta Academica Supplementum, 3.

Bringle, R. G., Games, R., \& Malloy, E. A. (Eds.). (1999). Colleges and universities as citizens. Needham Heights, MA: Allyn \& Bacon.

Bringle, R. G., \& Hatcher, J. A. (1995). A service-learning curriculum for faculty. Michigan Journal of Community Service Learning, 2, 112-122. 
Bringle, R. G., \& Hatcher, J. A., (2006, October). Where's the community impact in servicelearning research. Panel presented at 6th Annual International Conference on Service-Learning Research, Portland, OR.

Bringle, R. G., Hatcher, J. A., \& Clayton, P. H. (2006a). The scholarship of civic engagement: Defining, documenting, and evaluating faculty work. To Improve the Academy, 25, 257-279.

Bringle, R. G., Hatcher, J. A., \& Holland, B. (2007). Conceptualizing civic engagement: Orchestrating change at a metropolitan university. Metropolitan Universities, 18(3), 57-74.

Bringle, R. G., Hatcher, J. A., \& McIntosh, R. (2006b). Analyzing Morton’s typology of service paradigms and integrity. Michigan Journal of Community Service Learning, 13(1), 5-15.

Bringle, R. G., \& Steinberg, K. (in press). Educating for informed community involvement. American Journal of Community Psychology.

Browne, D. L. (2001). Democratic Congo. In R. Marlow-Ferguson (Ed.), World education encyclopedia: A survey of educational systems world wide (2nd ed.). Detroit, MI: Gale Groups, Thomson Learning.

Camay, P., \& Gordon, A. (2002, July). Civil society as advocate for social change in pre-and post-transition societies: Building sound governance in South Africa. Paper presented at the ISTR Conference, Cape Town, South Africa. Johannesburg, SA: Co-operative for Research and Education.

Castle, J., \& Osman, R. (2003). Service learning in teacher education: An institutional model for an emerging practice. South African Journal of Higher Education, 17(1), 105-111.

Colby, A., Ehrlich, T., Beaumont, E., \& Stephens, J. (2003). Educating citizens: Preparing America's undergraduates for lives of moral and civic responsibility. San Francisco: JosseyBass.

Department of Education. (1997, August). Education white paper 3. A programme for higher education transformation. Government Gazette No. 18207. Pretoria: Government Printers.

Department of Education. (2004). Report of the technical team: Investigation into the state funding of experiential learning at higher education institutions. Pretoria: Government Printers.

Driscoll, A., Holland, B., Gelmon, S., \& Kerrigan, S. (1996). An assessment model for servicelearning: Comprehensive case studies of impact on faculty, students, community, and institutions. Michigan Journal of Community Service Learning, 3, 66-71.

Du Pre, R. (2003). Coping with change in South Africa. Adults Learning, October 10-11. 
Erasmus, M. A. (2005). Introduction: Community service learning and the South African research agenda. Acta Academica Supplementum, 3, 1-23.

Eyler, J., \& Giles, D. E., Jr. (1999). Where’s the learning in service-learning? San Francisco: Jossey-Bass.

Fourie, M. (2003). Beyond the ivory tower: Service learning for sustainable community development. South African Journal of Higher Education, 17(1), 31-37.

Furco, A. (1996). Service-learning: A balanced approach to experiential education. In Corporation for National Service (Ed.), Expanding boundaries: Serving and learning (pp. 2-6). Columbia, MD: The Cooperative Education Association.

Gibbons, M. (2006, September). Engagement as a core value in a mode 2 society. Paper presented at the CHE-HEQC/JET-CHESP conference on community engagement in higher education, Cape Town.

Giovannoni, M., Trefon, T., Kasongo Banga, J., \& Mwema, C. (2004). Acting on behalf (and in spite) of the state: NGOs and civil society associations in Kinshasa. In T. Trefon (Ed.), Reinventing order in the Congo: How people respond to state failure in Kinshasa (pp. 99-115). New York: ZED Books.

Higher Education Quality Committee (HEQC). (2006). Service-learning in the curriculum: A resource for higher education institutions. Pretoria: Council on Higher Education.

Higher Education Quality Committee/JET Education Services. (2006). A good practice guide and self-evaluation instruments for managing the quality of service-learning. Pretoria: Council on Higher Education.

Kellogg Commission on the Future of State, Land Grant Universities. (1999). Returning to our roots: The engaged institution. Washington, DC: NASULGC.

Langseth, M., \& Plater, W. M. (Eds.). (2004). Public work and the academy: An academic administrator's guide to civic engagement and service-learning. Bolton, MA: Anker.

Lazarus, J. (2001, November). A new contract between higher education and society: Responsiveness through a scholarship of engagement. Paper presented at the third consultative conference of the council on higher education.

Lazarus, J. (2005). Community engagement in higher education. Joint Education Trust Education Services Bulletin, 12, 5-8.

Lazarus, J. (2007). Embedding service learning in higher education in South Africa: The catalytic role of the CHESP initiative. Education for Change, 11(3), Special Issue: CSL. 
Lazarus, J., Erasmus, M., Nduna, J., Hendricks, D., \& Slamat, J. (2008). Embedding community engagement in higher education in South Africa. Education, Citizenship and Social Justice, 1(3), 57-83.CrossRef

Le Grange, L. (2005). The 'idea of engagement' and 'the African university in the 21st century': Some reflections. South African Journal of Higher Education, Special Issue, 1208-1219.

Lelo, M. (2003). Democratic Republic of Congo (Zaire). In D. M. Teferra \& P. C. Altbach (Eds.), African higher education: An international reference handbook (pp. 265-272). Bloomington, IN: Indiana University Press.

Levine, P. (2003, November). Service-learning research and the movement for youth civic engagement. Keynote address at the third annual international service-learning research conference, Salt Lake City, UT.

Lulat, Y. G. M. (2003). The development of higher education in Africa. In D. M. Teferra \& P. C. Altbach (Eds.), African higher education: An international reference handbook (pp. 15-31). Bloomington, IN: Indiana University Press.

Marais, L., \& Botes, L. (2006). Putting the horse before the cart: Policy research, partnerships and community service. Acta Academica Supplementum, 3, 178-202.

Marais, S., Naidoo, A., Donson, H., \& Nortje, C. (2007). Strategic violence prevention partnerships in a peri-urban South African town: The case of the Jamestown community project. African Safety Promotion Journal, 5(1), 19-30.

Mcllrath, L., \& MacLabhrainn, I. M. (2007). Higher education and civic engagement: International perspectives. Surrey, UK: Ashgate.

Metropolitan Universities, 14(2) (2003)

Mitchell, C., \& Humphries, H. (2007). From notions of charity to social justice in servicelearning: The complex experience of communities. Education for Change, 11(3), Special Issue: Community Service Learning.

Moely, B. E., \& Miron, D. (2005). College students' preferred approaches to community service: Charity and social change paradigms. In S. Root, J. Callahan, \& S. H. Billig (Eds.), Improving service-learning practice: Research on models to enhance impacts (pp. 61-78). Greenwich, CN: Information Age Publishing.

Morton, K. (1995). The irony of service: Charity, project, and social change in service-learning. Michigan Journal of Community Service Learning, 2, 19-32.

Naidoo, A. V., Duncan, N., Roos, V., Pillay, J., \& Bowman, B. (2007). Analysis, context and action: An introduction to community psychology. In N. Duncan, A. V. Naidoo, J. Pillay, \& V. 
Roos (Eds.), Community psychology in South Africa: Theory, context and practice (pp. 9-23). Wetton, RSA: UCT Press.

Naidoo, A. V., \& Van Wyk, S. B. (2003). Intervening in communities: Combining curative and preventive interventions. Journal of Prevention and Intervention in the Community, 25(1), 6580.CrossRef

Naidoo, A. V., Van Wyk, S. B., \& Carolissen, R. (2004). Community mental health. In L. Swartz, C. de la Rey, \& N. Duncan (Eds.), Psychology: An introduction (pp. 513-526). Cape Town: Oxford University Press.

Nduna, J. (2007). The community voice on service-learning. A good practice guide for higher education. Education for Change, 11(3), Special Issue: CSL.

Njongola-Ntalaja, G. (2004). From Zaire to the Democratic Republic of Congo (2nd and revised ed.). Uppsala: Nordiska Afrikainstitutet.

Osborne, R. E., Hammerich, S., \& Hensley, C. (1998). Student effects of service-learning:

Tracking change across a semester. Michigan Journal of Community Service Learning, 5, 5-13.

Perold, H. (1998). Community service in higher education: Final report. Braamfontein: Joint Education Trust.

Perold, H., Stroud, S., \& Sherraden, M. (Eds.). (2003). Service enquiry. Service in the 21st Century (pp. 47-58). Cape Town, South Africa: Compress.

Perry, J. L., \& Thomson, A. M. (2004). Civic service: What difference does it make? Armonk, NY: M. E. Sharpe.

Peters, S. J., Jordan, N. R., Adamek, M., \& Alter, T. R. (Eds.). (2006). Engaging campus and community: The practice of public scholarship in the state and land-grant university system. Dayton, OH: Charles F. Kettering Foundation.

Prilleltensky, I. (2001). Value-based praxis in community psychology: Moving toward social justice and social action. American Journal of Community Psychology, 29, 747-778.CrossRef

Rotberg, R. (2003). State failure and state weakness in a time of terror. Washington, DC: Brookings Institute Press.

Schudson, M. (2003). How people learn to be civic. Campus Compact Reader, Winter 14-21.

Stellenbosch University (SU). (2007). Stellenbosch service-learning capacity building program 2005/6. Report to community-higher education-service partnerships on service-learning capacity building program, Unpublished. 
Thelin, J. R. (2004). A history of American higher education. Baltimore, MD: Johns Hopkins University Press.

Thomas, N. L. (1998). The institution as a citizen: How colleges and universities enhance their civic roles. Working Paper \#22, New England Resource Center for Higher Education. Boston, MA: University of Massachusetts Boston.

Thomson, A. M. (2006). Field notes: Democratic Republic of Congo.

Trefon, T. (2004). Reinventing order in the Congo: How people respond to state failure in Kinshasa. New York: ZED Books.

United Board for Christian Higher Education in Asia and International Christian University. (2002). Service learning in Asia: Creating networks and curricula in higher education. Tokyo, Japan: International Christian University.

Wandersman, A., \& Florin, P. (1999). Citizen participation and community organizations. In J. Rappaport \& E. Seidman (Eds.), Handbook of community psychology (pp. 247-272). New York: Kluwer Academic/Plenum Publishers.

Westheimer, J., \& Kahne, J. (2003, Winter). What kind of citizen? Political choices and educational goals. Campus Compact Reader, 1-13.

World Bank. (2005). Education in the Democratic Republic of Congo: Priorities and options for regeneration. Washington, DC: World Bank.

\section{Footnotes}

See Bringle and Steinberg (in press) for a discussion of what constitutes a civic-minded graduate. They identify seven core elements that signify a civic-minded graduate that include: (1) academic knowledge and technical skills, (2) knowledge of volunteer opportunities and nonprofit organizations, (3) knowledge of contemporary and social issues, (4) listening and communication skills, (5) diversity skills, (6) self-efficacy, and (7) behavioral intentions as a predictor of civically engaged behavior. 
Table 1. Comparative analysis of community engagement in three contexts

\begin{tabular}{|c|c|c|c|}
\hline Dimensions & United States (US) & $\begin{array}{l}\text { Republic of South Africa } \\
\text { (RSA) }\end{array}$ & $\begin{array}{l}\text { Democratic Republic of } \\
\text { Congo (DRC) }\end{array}$ \\
\hline $\begin{array}{l}\text { 1. Economic } \\
\text { context }\end{array}$ & Developed country & $\begin{array}{l}\text { Relatively stable developing } \\
\text { country }\end{array}$ & An underdeveloped country \\
\hline $\begin{array}{l}\text { 2. Political } \\
\text { context }\end{array}$ & $\begin{array}{l}\text { Strong independent } \\
\text { democratic institutions }\end{array}$ & $\begin{array}{l}\text { Public state controlled HE } \\
\text { in an evolving democracy }\end{array}$ & $\begin{array}{l}\text { Absence of functioning } \\
\text { democratic public institutions }\end{array}$ \\
\hline $\begin{array}{l}\text { 3. Higher } \\
\text { education (HE) } \\
\text { and the state }\end{array}$ & $\begin{array}{l}\text { No government mandate } \\
\text { (Except for land-grant } \\
\text { universities) }\end{array}$ & $\begin{array}{l}\text { State-mobilized higher } \\
\text { education for national } \\
\text { reconstruction of historical } \\
\text { racial divisions }\end{array}$ & $\begin{array}{l}\text { High level of chaos in HE due } \\
\text { to generations of devastating } \\
\text { political and economic effects } \\
\text { of civil war and violence; } \\
\text { currently no comprehensive } \\
\text { education policy }\end{array}$ \\
\hline $\begin{array}{l}\text { 4. Civic role of } \\
\mathrm{HE}\end{array}$ & $\begin{array}{l}\text { Discretionary and open to } \\
\text { self-definition by } \\
\text { institutions within the } \\
\text { context of their individual } \\
\text { mission statements }\end{array}$ & $\begin{array}{l}\text { Clear policy guidelines for } \\
\text { contribution to the } \\
\text { development agenda and } \\
\text { producing civic-minded } \\
\text { graduates }\end{array}$ & $\begin{array}{l}\text { Civic role of HE remains } \\
\text { largely undefined with small } \\
\text { but limited attempts to } \\
\text { strengthen university-society } \\
\text { relationships; history of } \\
\text { teachers unions and labor } \\
\text { strikes }\end{array}$ \\
\hline $\begin{array}{l}5 . \\
\text { Development } \\
\text { of service as } \\
\text { the third core } \\
\text { function in HE }\end{array}$ & $\begin{array}{l}\text { A distinct shift from top- } \\
\text { down elitist outreach to } \\
\text { service with and in the } \\
\text { community. Service is } \\
\text { integrated in teaching and } \\
\text { research }\end{array}$ & $\begin{array}{l}\text { A distinct shift from } \\
\text { peripheral volunteer } \\
\text { activities to curriculum- } \\
\text { based engagement guided } \\
\text { by HE transformational } \\
\text { legislation and subsequent } \\
\text { response by institutions }\end{array}$ & $\begin{array}{l}\text { Service seen primarily in terms } \\
\text { of the internal needs of } \\
\text { institutions of HE and/or as } \\
\text { pre-professional training (strict } \\
\text { boundaries between university } \\
\text { and community) }\end{array}$ \\
\hline $\begin{array}{l}\text { 6. Student } \\
\text { forms of } \\
\text { engagement }\end{array}$ & $\begin{array}{l}\text { Curricular and co- } \\
\text { curricular with primary } \\
\text { focus on student outcomes } \\
\text { with possible long-term } \\
\text { outcomes for community }\end{array}$ & $\begin{array}{l}\text { Curricular, work-based and } \\
\text { volunteer activities to } \\
\text { benefit both student and } \\
\text { community }\end{array}$ & $\begin{array}{l}\text { Activism limited largely to } \\
\text { campus based reform rather } \\
\text { than broader social and } \\
\text { political reform }\end{array}$ \\
\hline $\begin{array}{l}\text { 7. “Civic } \\
\text { engagement” } \\
\text { versus } \\
\text { “Community } \\
\text { engagement” }\end{array}$ & $\begin{array}{l}\text { "Community involvement” } \\
\text { seen as an umbrella term } \\
\text { that includes wide range of } \\
\text { informal to formal } \\
\text { connection with local } \\
\text { communities. "Civic } \\
\text { engagement” denotes } \\
\text { faculty and students } \\
\text { working with communities } \\
\text { as a form of citizenship; } \\
\text { civic directly linked to } \\
\text { democratic theory of } \\
\text { citizenship }\end{array}$ & $\begin{array}{l}\text { “Community engagement” } \\
\text { as overarching concept; } \\
\text { different concepts } \\
\text { developed across } \\
\text { universities that imply an } \\
\text { interactive equal and } \\
\text { reciprocal relationship. } \\
\text { "Civic” points to human } \\
\text { rights actions associated } \\
\text { with suppression and } \\
\text { opposing political } \\
\text { ideologies }\end{array}$ & $\begin{array}{l}\text { “Community engagement” is } \\
\text { narrowly defined: refers to } \\
\text { work-based learning, informal } \\
\text { faculty support of communities } \\
\text { and student self-help groups on } \\
\text { campus. Meaning of "civic } \\
\text { engagement” largely irrelevant } \\
\text { in context of a failed state; } \\
\text { does not resonate with } \\
\text { individual capacity to influence } \\
\text { political institutions for the } \\
\text { public good }\end{array}$ \\
\hline
\end{tabular}


Figure 1. Engagement of faculty work in and with community

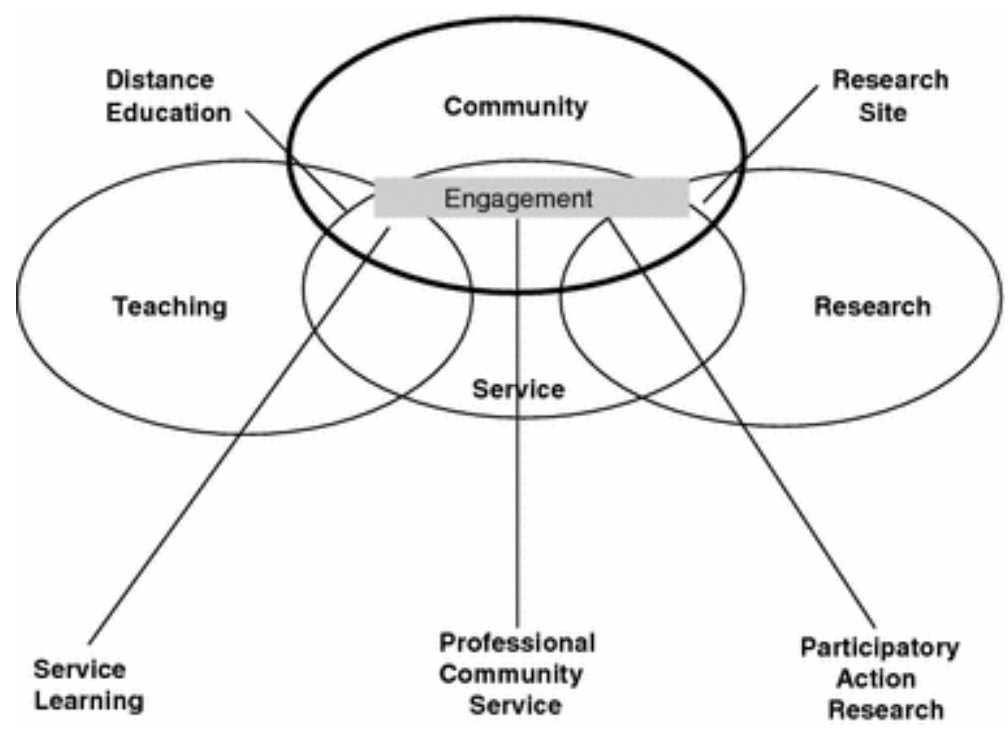


Figure 2. Conceptual framework for design of SL programs (Adapted from Naidoo et al. 2004)

\begin{tabular}{|c|c|c|}
\hline MICRO CONTEXT & & $\rightarrow$ MACRO CONTEXT \\
\hline INDIVIDUAL FOCUS & & $\longrightarrow$ COMMIUNITY FOCUS \\
\hline $\begin{array}{c}\text { AMELIORATION } \longleftarrow \\
\downarrow\end{array}$ & $\downarrow$ & $\rightarrow$ TRANSFORMATION \\
\hline $\begin{array}{l}\text { Charity-Based Approaches } \\
\text { Providing Direet Service to } \\
\text { Community Members in Need }\end{array}$ & $\begin{array}{l}\text { Project-based Approaches } \\
\text { Implementing or Participating } \\
\text { in Community Service Programs } \\
\text { Through Third Sector Organizations }\end{array}$ & $\begin{array}{l}\text { Social Change Approaches } \\
\text { Challenging the Status Quo } \\
\text { and Addressing Structural } \\
\text { Conditions of Injustice } \\
\text { (Soctal, Political, Economic) }\end{array}$ \\
\hline $\begin{array}{l}\text { Examples: } \\
\text { * Humanitarian responses to immediate needs } \\
\text { (victims of natural disasters) } \\
\text { * Traditional social service } \\
\text { * Short-term volunteer work } \\
\text { * Co-curricular community service }\end{array}$ & $\begin{array}{l}\text { Working in Third-sector organizations to } \\
\text { assist with various projects (setting up a } \\
\text { micro-credit program, after-school tutoring } \\
\text { program, working in a health clinic) } \\
\text { May be long-term but usually short-term } \\
\text { partnerships focused on filling service } \\
\text { gaps in third sector organizations }\end{array}$ & $\begin{array}{l}\text { * Negotiating long-term } \\
\text { partnerships between university, } \\
\text { community members, and third } \\
\text { sector organizations based on } \\
\text { addressing systemic change } \\
\text { * Community campaigns, policy } \\
\text { development } \\
\text { - Values indigenous knowledge fo } \\
\text { social and community } \\
\text { mobilization on their own } \\
\text { behalf to change status quo } \\
\text { institutions } \\
\text { - Participating in action research }\end{array}$ \\
\hline
\end{tabular}

